\title{
PERBEDAAN KEMAMPUAN PEMECAHAN MASALAH DAN MOTIVASI BELAJAR YANG DIAJAR MELALUI MODEL PEMBELAJARAN KOOPERATIF DENGAN KONTEKSTUAL BERBANTUAN SOFTWARE GEOGEBRA
}

\author{
Doni Irawan Saragih ${ }^{1}$, Ani Minarni ${ }^{2}$, Mukhtar $^{2}$
}

\begin{abstract}
ABSTRAK
Tujuan dari penelitian ini adalah untuk : (1) menganalisis perbedaan kemampuan pemecahan masalah matematis siswa yang belajar melalui model pembelajaran kooperatif dengan model pembelajaran kontekstual berbantuan software GeoGebra, (2) menganalisis perbedaan motivasi belajar siswa yang belajar melalui model pembelajaran kooperatif dengan model pembelajaran kontekstual berbantuan software GeoGebra, (3) mengetahui apakah terdapat interaksi antara model pembelajaran dan gender siswa terhadap kemampuan pemecahan masalah matematis siswa, (4) mengetahui apakah terdapat interaksi antara model pembelajaran dan gender siswa terhadap motivasi belajar siswa, (5) menganalisis proses penyelesaian jawaban tes kemampuan pemecahan masalah matematis siswa yang belajar melalui model pembelajaran kooperatif dengan model pembelajaran kontekstual berbantuan software geogebra. Instrumen yang digunakan terdiri dari : (1) tes kemampuan pemecahan masalah matematis, (2) angket motivasi belajar. Analisis data dilakukan dengan analisis varians (ANAVA) dua jalur. Hasil penelitiaan menunjukkan : (1) terdapat perbedaan kemampuan pemecahan masalah matematis siswa yang belajar melalui model pembelajaran kooperatif dan model pembelajaran kontekstual berbantuan software GeoGebra, (2) terdapat perbedaan motivasi belajar siswa yang belajar melalui model pembelajaran kooperatif dan model pembelajaran kontekstual berbantuan software GeoGebra, (3) terdapat interaksi antara model pembelajaran dan gender terhadap kemampuan pemecahan masalah matematis siswa, (4) terdapat interaksi antara model pembelajaran dan gender terhadap motivasi belajar siswa, (5) proses penyelesaian jawaban siswa kelas model pembelajaran kontekstual lebih baik dibandingkan kelas model pembelajaran kooperatif.
\end{abstract}

Kata Kunci: Model pembelajaran kooperatif, Model pembelajaran kontekstual, Pemecahan masalah, Motivasi belajar

\section{PENDAHULUAN}

Pendidikan adalah segala kegiatan pembelajaran yang berlangsung sepanjang zaman dalam segala situasi kegiatan kehidupan. Pendidikan merupakan usaha yang dilakukan oleh keluarga, masyarakat, dan pemerintah melalui kegiatan bimbingan, pengajaran dan latihan, yang berlangsung di sekolah dan di luar sekolah sepanjang hayat untuk mempersiapkan peserta didik agar dapat mempermainkan peranan dalam berbagai jenis lingkungan secara tetap untuk masa yang akan datang. Tentu pendidikan merupakan tanggung jawab orang tua terhadap anaknya dan negara terhadap rakyatnya (Saragih, 2017). Dan pendidikan merupakan satuan tindakan yang mendorong terjadinya belajar serta dengan belajarlah terjadi perkembangan jasmani dan mental siswa.

Dalam kegiatan belajar mengajar di sekolah, matematika merupakan pelajaran penting yang

${ }^{1}$ Corresponding Author: Doni Irawan Saragih

Program Magister Pendidikan Matematika, Universitas Negeri Medan, Medan, 20221, Indonesia

E-mail: doniirawansaragih@gmail.com

${ }^{2}$ Co-Author: Ani Minarni \& Mukhtar

Program Studi Pendidikan Matematika, Universitas Negeri Medan, Medan, 20221, Indonesia tentunya dituntut untuk mampu diaplikasikan dalam kehidupan nyata siswa. Di sisi lain, fungsi matematika adalah sebagai media atau sarana siswa dalam mencapai kompetensi. Dengan mempelajari materi matematika diharapkan siswa akan menguasai seperangkat kompetensi yang telah ditetapkan. Oleh karena itu, penguasaan materi matematika bukanlah tujuan akhir dari pembelajaran matematika, akan tetapi penguasaan materi matematika hanyalah jalan mencapai penguasaan kompetensi, seperti halnya kompetensi dalam memecahkan masalah matematis. NCTM (Husna, Ikhsan, \& Fatimah, 2013) mengemukakan bahwa pemecahan masalah merupakan proses menerapkan pengetahuan yang telah diperoleh sebelumnya pada situasi baru dan berbeda. Pemecahan masalah adalah bagian dari kurikulum matematika yang sangat penting karena berartinya proses pembelajaran dan penyelesaiannya (Ritonga, Surya, \& Syahputra, 2017). Kemampuan pemecahan masalah adalah kemampuan atau kompetensi strategis yang ditunjukkan siswa dalam memahami, memilih pendekatan dan strategi serta model yang lengkap untuk menemukan solusi dari suatu masalah (Lubis, Panjaitan, Surya, \& Syahputra, 2017). 
Peringkat hasil TIMSS 2015 untuk sekolah lanjutan, Indonesia memperoleh skor 397 dan menduduki peringkat 46 dari 51 Negara, yang artinya hanya mampu menjawab $4 \%$ soal dengan benar. Dan berdasarkan PISA 2015, Indonesia memperoleh skor 386 dan menduduki peringkat 69 dari 76 Negara (PPPPTK, 2015). Hasil TIMSS dan PISA tersebut menggambarkan bahwa kemampuan pemecahan masalah siswa Indonesia dalam matematika yang melibatkan pengetahuan, penerapan dan penalaran masih sangat rendah di tingkat internasional.

Berdasarkan tes diagnostik yang diberikan, dapat disimpulkan bahwa siswa SMP Budi Agung Medan memiliki kemampuan pemecahan masalah matematis dalam kategori kurang, terutama pada tahap ke-2, yakni merencanakan pemecahan terhadap permasalahan dan pada tahap ke-4, yakni melakukan konfirmasi terhadap permasalahan yang diajukan. Hal tersebut sesuai dengan penelitian yang berjudul "On Eight Grade Students Understanding in Solving Mathematical Problems" (Minarni, 2017), yang menyatakan bahwa, pada aspek menentukan model matematika, siswa dapat melakukannya dengan baik, dan siswa menghadapi kesulitan pada aspek merencanakan penyelesaian dan menjelaskan solusi terhadap masalah yang diajukan.

Sisi lain yang juga dianggap penting dalam pembelajaran adalah sisi afektif, termasuk aspek motivasi. Motivasi merupakan salah satu faktor yang turut menentukan keefektifan dan keberhasilan pembelajaran, karena peserta didik akan belajar dengan sungguh-sungguh apabila memiliki motivasi yang tinggi (Nayazik, 2012). Berdasarkan observasi dan wawancara dengan guru mata pelajaran matematika di SMP Budi Agung Medan, motivasi belajar siswa khususnya di kelas VIII masih dalam kategori rendah.

Di sisi lain, pemanfaatan teknologi dalam proses pembelajaran di SMP Budi Agung Medan juga belum maksimal. Padahal, Teknologi Informasi dan Komunikasi (TIK) telah digunakan dalam pendidikan sejak awal teknologi itu ditemukan, dan digunakan besar-besaran sejak awal 1980-an (Darmawijoyo, 2011). Maka, pemanfaatan software GeoGebra merupakan hal yang penting untuk diterapkan dalam kegiatan belajar mengajar. Dan penggunaan GeoGebra efektif untuk memodelkan strategi pembelajaran untuk peningkatan dan perubahan dalam pedagogi guru (Escuder \& Furner, 2012). Dan pendapat lain mengemukakan bahwa siswa memiliki persepsi positif terhadap pembelajaran dan memiliki prestasi belajar yang lebih baik menggunakan GeoGebra (Arbain \& Shukor, 2015).

\section{KAJIAN TEORITIS}

\section{Kemampuan Pemecahan Masalah Matematis}

Masalah merupakan sesuatu yang gagal atau tidak bekerja dengan baik sesuai dengan yang diharapkan. Dalam pembelajaran matematika, suatu pertanyaan akan menjadi masalah hanya jika pertanyaan itu menunjukkan adanya suatu tantangan (challenge) yang tidak dapat dipecahkan oleh prosedur rutin yang sudah diketahui oleh siswa. Menurut Lencher (dalam Wardhani, dkk., 2010), memecahkan masalah matematis adalah proses menerapkan pengetahuan matematika yang telah diperoleh sebelumnya ke dalam situasi baru yang belum dikenal siswa.

Minarni (2017) menyatakan bahwa ketika siswa memecahkan masalah matematika, mereka sedang membangun keterampilan matematika lainnya seperti kemampuan pemahaman, kemampuan representasi matematis, dll. Polya (1973) mengemukakan empat tahapan atau langkah yang dapat ditempuh dalam pemecahan masalah yaitu (a) memahami masalah, (b) membuat rencana pemecahan, (c) melakukan perhitungan dan (d) memeriksa kembali hasil yang diperoleh.

\section{Motivasi Belajar}

Motivasi adalah perubahan energi dalam diri seseorang yang ditandai dengan munculnya feeling dan didahului dengan tanggapan terhadap adanya tujuan (Jariswandana, Yerizon, \& Nilawasti, 2012). Menurut Watters and Ginns (dalam Guvendir, 2013), motivasi adalah konstruksi psikologis yang kompleks yang mencoba menjelaskan perilaku dan usaha yang diterapkan dalam berbagai aktivitas. Lebih lanjut Dornyei (2001) menyatakan bahwa, "motivasi adalah perubahan dinamis yang ada dalam diri seseorang secara kumulatif yang memulai, mengarahkan, yang mengkoodinasikan, yang memperkuat, yang membatasi, dan yang mengevaluasi proses kognitif dan motorik dengan jalan permulaan yang diharapkan dipilih, diperioritaskan, dioperasikan dan dilaksanakan."

Berdasarkan sumbernya, motivasi terbagi menjadi dua macam, yaitu motivasi intrinsik dan motivasi ekstrinsik (Dimyati \& Mudjiono, 2009). Uno (2014) menjelaskan bahwa faktor instrinsik berupa hasrat atau keinginan berhasil dan dorongan kebutuhan belajar serta harapan akan cita-cita yang ingin dicapai. Sedangkan faktor ekstrinsik adalah faktor karena adanya penghargaan, lingkungan belajar yang kondusif, dan kegiatan belajar yang menarik.

Berdasarkan indikator-indikator motivasi dari Wena (2011) dan Uno (2014), penulis mengangkat indikator motivasi belajar dalam penelitian ini sebagai berikut: Adanya hasrat dan keinginan berhasil,

1. Adanya dorongan dan kebutuhan dalam belajar,

2. Adanya perhatian siswa terhadap pembelajaran,

3. Adanya keyakinan siswa terhadap kemampuannya dalam mengerjakan tugas-tugas pembelajaran,

4. Adanya kegiatan yang menarik dalam belajar

5. Adanya kepuasan siswa terhadap proses pembelajaran yang telah dilaksanakan.

\section{METODE PENELITIAN}

Penelitian ini dikategorikan dalam penelitan eksperimen semu, yang dilakukan di SMP Budi Agung Medan dengan seluruh siswa kelas VIII sebagai populasi dan kelas $\mathrm{VIII}^{4}$ (eksperimen I) dan VIII $^{1}$ (eksperimen II) sebagai sampel. Rancangan yang digunakan dalam penelitian ini adalah Pretest Posttest Control Group Design seperti pada Tabel 1 berikut :

Perbedaan Kemampuan Pemecahan Masalah dan Motivasi Belajar yang Diajar Melalui Model Pembelajaran Kooperatif dengan Kontekstual Berbantuan Geogebra 


\begin{tabular}{llll}
\multirow{2}{*}{ Eksperimen II } & Lk & 15 & 77,80 \\
\cline { 2 - 4 } & $\operatorname{Pr}$ & 15 & 76,07 \\
\hline
\end{tabular}

Tabel 1. Desain Penelitian

\begin{tabular}{cccc}
\hline Kelompok & $\begin{array}{c}\text { Tes } \\
\text { Diagnostik }\end{array}$ & Perlakuan & $\begin{array}{c}\text { Post } \\
\text { Test }\end{array}$ \\
\hline Eksperimen I & $\mathrm{T}_{1}$ & $\mathrm{X}_{1}$ & $\mathrm{~T}_{2}$ \\
\hline Eksperimen II & $\mathrm{T}_{1}$ & $\mathrm{X}_{2}$ & $\mathrm{~T}_{2}$ \\
\hline
\end{tabular}

Instrument, Teknik Pengumpulan Data dan Teknik Analisis Data

Teknik analisis data yang digunakan dalam penelitian ini adalah Analisis statistik deskriptif digunakan untuk melihat proses jawaban tes kemampuan pemecahan masalah matematis siswa dan Analisis statistik inferensial digunakan untuk menguji hipotesis penelitian. Data yang diperoleh dari skor kemampuan pemecahan masalah matematis dan motivasi belajar siswa dikelompokkan menurut kelompok pembelajaran (kooperatif dan kontekstual) secara heterogen.

Pengolahan data dalam pengujian hipotesis diawali dengan menguji prasyarat statistik yang diperlukan, yaitu uji normalitas dan uji homogenitas varians. Selanjutnya dilakukan analisis varians (ANAVA) dua jalur. Seluruh perhitungan statistik menggunakan bantuan program komputer SPSS. 16 dan program Microsoft Excel.

\section{HASIL PENELITIAN}

Deskripsi Kemampuan Awal Matematis (KAM) Siswa

Kemampuan awal matematis (KAM) adalah pengetahuan yang dimiliki siswa sebelum pembelajaran berlangsung. Berikut hasil perhitungan rata-rata dan simpangan baku KAM seperti yang tertera pada Tabel 2 berikut:

Tabel 2. Deskrpsi Data KAM

\begin{tabular}{ccccccc}
\hline Kelas & $\begin{array}{c}\text { Skor } \\
\text { Ideal }\end{array}$ & $\mathbf{N}$ & $\begin{array}{c}\text { Xm } \\
\text { in }\end{array}$ & $\begin{array}{c}\text { Xm } \\
\text { aks }\end{array}$ & $\begin{array}{c}\bar{x} \\
\text { SD }\end{array}$ \\
\hline $\begin{array}{c}\text { Eksperim } \\
\text { en I }\end{array}$ & & 3 & \multirow{2}{*}{100} & 78 & $\begin{array}{c}52, \\
80\end{array}$ & $\begin{array}{c}17, \\
06\end{array}$ \\
\cline { 1 - 6 } $\begin{array}{c}\text { Eksperim } \\
\text { en II }\end{array}$ & & 3 & 31 & 78 & $\begin{array}{c}53, \\
50\end{array}$ & $\begin{array}{c}16, \\
80\end{array}$ \\
\hline
\end{tabular}

Hasil Post Test Kemampuan Pemecahan Masalah Matematis Siswa

Dari hasil post test kemampuan pemecahan masalah matematis siswa dideskripsikan sebagai berikut:

Tabel 3. Deskripsi Post Test Berdasarkan Gender

\begin{tabular}{cccc}
\hline Kelas & Gender & N & Rata-Rata \\
\hline \multirow{2}{*}{ Eksperimen I } & Lk & 16 & 66,44 \\
\cline { 2 - 4 } & Pr & 14 & 75,07 \\
\hline
\end{tabular}

Tabel 4. Post Test Berdasarkan Tahap Kemampuan Pemecahan Masalah

\begin{tabular}{ccc}
\hline Tahap KPMM & $\begin{array}{c}\text { Kelas } \\
\text { Eksperimen I }\end{array}$ & $\begin{array}{c}\text { Kelas } \\
\text { Eksperimen II }\end{array}$ \\
\hline Memahami Masalah & 3,50 & 3,67 \\
\hline $\begin{array}{c}\text { Merencanakan } \\
\text { Pemecahan }\end{array}$ & 3,14 & 3,38 \\
\hline Melakukan Perhitungan & 2,56 & 2,91 \\
\hline Memeriksa Kembali & 0,67 & 0,82 \\
\hline
\end{tabular}

Motivasi Belajar Siswa Setelah diberi Perlakuan

Motivasi belajar siswa dipandang dari 2 sumber, yaitu motivasi intrinsik (indikator $1 \mathrm{~s} / \mathrm{d} 4$ ) dan motivasi ekstrinsik (indikator 5 dan 6). Adapun hasil motivasi belajar siswa setelah diberi perlakuan dideskripsikan pada Tabel 5 dan Tabel 6 berikut:

Tabel 5. Motivasi Belajar Siswa Berdasarkan Indikator Motivasi Belajar Siswa

\begin{tabular}{lcc}
\hline \multicolumn{1}{c}{ Indikator } & \multicolumn{2}{c}{ Rata-rata Skor } \\
\cline { 2 - 3 } & $\begin{array}{c}\text { Eksperi } \\
\text { men I }\end{array}$ & $\begin{array}{c}\text { Eksperim } \\
\text { en II }\end{array}$ \\
\hline $\begin{array}{l}\text { Adanya hasrat dan } \\
\text { keinginan berhasil }\end{array}$ & 75,8 & 83,1 \\
\hline $\begin{array}{l}\text { Adanya dorongan dan } \\
\text { kebutuhan dalam } \\
\text { belajar }\end{array}$ & 81,4 & 80,8 \\
\hline $\begin{array}{l}\text { Adanya perhatian } \\
\text { siswa terhadap } \\
\text { pembelajaran }\end{array}$ & 83,8 & 83,8 \\
\hline $\begin{array}{l}\text { Adanya keyakinan } \\
\text { siswa terhadap } \\
\text { kemampuannya dalam } \\
\text { mengerjakan tugas- } \\
\text { tugas pembelajaran }\end{array}$ & 81,5 & 70,4 \\
\hline $\begin{array}{l}\text { Adanya kegiatan yang } \\
\text { menarik dalam belajar }\end{array}$ & 86,9 & 83,5 \\
\hline $\begin{array}{l}\text { Adanya kepuasan } \\
\text { siswa terhadap proses } \\
\text { pembelajaran yang } \\
\text { telah dilaksanakan }\end{array}$ & 81,8 & 80,3 \\
\hline
\end{tabular}

Tabel 6. Skor Motivasi Belajar Siswa Berdasarkan Gender

\begin{tabular}{cccc}
\hline Kelas & Gender & N & Rata-Rata \\
\hline \multirow{2}{*}{ Eksperimen I } & $\mathrm{Lk}$ & 16 & 82,62 \\
\cline { 2 - 4 } & $\mathrm{Pr}$ & 14 & 82,07 \\
\hline $\begin{array}{c}\text { Eksperimen } \\
\text { II }\end{array}$ & $\mathrm{Lk}$ & 15 & 78,73 \\
\cline { 2 - 4 } & $\mathrm{Pr}$ & 15 & 82,67 \\
\hline
\end{tabular}

Berdasarkan analisis pada indikator motivasi belajar siswa, diperoleh bahwa pada model pembelajaran kooperatif, rata-rata motivasi intrinsik siswa laki-laki

Perbedaan Kemampuan Pemecahan Masalah dan Motivasi Belajar yang Diajar Melalui Model Pembelajaran Kooperatif dengan Kontekstual Berbantuan Geogebra 


\section{PARADIKMA JURNAL PENDIDIKAN MATEMATIKA}

Vol. 13, No. 2, Desember 2020

sebesar 81,9, dan motivasi intrinsik siswa perempuan sebesar 79,2. Sedangkan motivasi ekstrinsik siswa lakilaki sebesar 83,6, dan motivasi ekstrinsik siswa perempuan sebesar 85,3 . Secara keseluruhan, motivasi intrinsik kelas model pembelajaran kooperatif sebesar 80,5, dan motivasi ekstrinsik sebesar 84,4. Seiring demikian, pada model pembelajaran kontekstual, ratarata motivasi intrinsik siswa laki-laki sebesar 76,4, dan motivasi intrinsik siswa perempuan sebesar 82,7. Sedangkan motivasi ekstrinsik siswa laki-laki sebesar 81,5 , dan motivasi ekstrinsik siswa perempuan sebesar 82,2. Secara keseluruhan, motivasi intrinsik kelas model pembelajaran kontekstual sebesar 79,5, dan motivasi ekstrinsik sebesar 81,9. Hal ini menunjukkan bahwa motivasi ekstrinsik siswa lebih dominan dibandingkan motivasi intrinsik siswa.

\section{Pengujian Hipotesis 1 dan 3}

Kriteria pengujian untuk menguji hipotesis adalah jika $\mathrm{F}_{0}>\mathrm{F}_{\text {tabel }}$ maka tolak $\mathrm{H}_{0}$ dan terima Ha. Adapun hasil uji hipotesis yang pertama dengan uji ANAVA Dua Jalur dideskripsikan pada Tabel 7 berikut:

Tabel 7. Uji Hipotesis 1 dan 3 ANAVA Dua Jalur dengan Excel

\begin{tabular}{ccccccc}
\hline $\begin{array}{c}\text { Sumber } \\
\text { Varians }\end{array}$ & JK & $\begin{array}{c}\mathrm{D} \\
\mathrm{b}\end{array}$ & $\mathrm{RJK}$ & $\mathrm{F}_{0}$ & $\mathrm{~F}_{\text {tab }}$ & $\begin{array}{c}\text { Peng } \\
\text { aruh }\end{array}$ \\
\hline Gender & $\begin{array}{c}192.6 \\
99\end{array}$ & 1 & $\begin{array}{c}192 . \\
699\end{array}$ & $\begin{array}{c}2.0 \\
27\end{array}$ & $\begin{array}{c}4.0 \\
13\end{array}$ & $\begin{array}{c}0.034 \\
925\end{array}$ \\
\hline Model & $\begin{array}{c}640.2 \\
67\end{array}$ & 1 & $\begin{array}{c}640 . \\
267\end{array}$ & $\begin{array}{c}6.7 \\
34\end{array}$ & $\begin{array}{c}4.0 \\
13\end{array}$ & $\begin{array}{c}0.107 \\
337\end{array}$ \\
\hline $\begin{array}{c}\text { Interaksi } \\
\text { Gender* } \\
\text { Model }\end{array}$ & $\begin{array}{c}390.0 \\
35\end{array}$ & 1 & $\begin{array}{c}390 . \\
035\end{array}$ & $\begin{array}{c}4.1 \\
02\end{array}$ & $\begin{array}{c}4.0 \\
13\end{array}$ & $\begin{array}{c}0.068 \\
25\end{array}$ \\
\hline Dalam & $\begin{array}{c}5324 . \\
733\end{array}$ & 5 & 95.0 & & & \\
\hline Total & 6547. & 5 & & & & \\
\hline 733 & 9 & & & & \\
\hline
\end{tabular}

Berdasarkan tabel di atas, terlihat bahwa pada baris model nilai $F_{0}$ sebesar 6,734 dan nilai $F_{\text {tab }}$ sebesar $4,013\left(\mathrm{~F}_{0}>\mathrm{F}_{\mathrm{tab}}\right)$ dan dengan pengaruh sebesar $10,73 \%$. Hal ini menunjukkan bahwa terdapat perbedaan kemampuan pemecahan masalah matematis siswa yang belajar melalui model pembelajaran kooperatif dengan model pembelajaran kontekstual berbantuan software geogebra.

Pada baris gender*model, nilai $\mathrm{F}_{0}$ sebesar 4,102 dan $F_{\text {tab }}$ sebesar 4,013 $\left(F_{0}>F_{\text {tab }}\right)$. Hal ini menunjukkan bahwa terdapat interaksi antara model pembelajaran (kooperatif dan kontekstual) berbantuan software geogebra dengan gender siswa terhadap kemampuan pemecahan masalah matematis siswa. Hal ini juga dapat dideskripsikan pada Gambar 1 berikut:

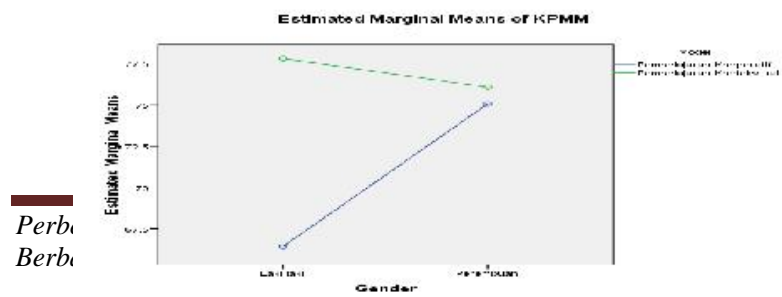

Gambar 1. Interaksi Antara Model Pembelajaran dan Gender Terhadap Kemampuan Pemecahan Masalah Matematis Siswa

\section{Pengujian Hipotesis 2 dan 4}

Adapun hasil uji hipotesis yang pertama dengan uji ANAVA Dua Jalur dideskripsikan pada Tabel 8 berikut:

Tabel 8. Uji Hipotesis 2 dan 4 dengan Anava Dua Jalur

\begin{tabular}{ccccccc}
\hline $\begin{array}{c}\text { Sumber } \\
\text { Varians }\end{array}$ & JK & $\begin{array}{c}\mathrm{d} \\
\mathrm{b}\end{array}$ & $\mathrm{RJK}$ & $\mathrm{F}_{0}$ & $\mathrm{~F}_{\text {tab }}$ & $\begin{array}{c}\text { Penga } \\
\text { ruh }\end{array}$ \\
\hline Gender & $\begin{array}{c}40.1 \\
70\end{array}$ & 1 & $\begin{array}{c}40.1 \\
70\end{array}$ & $\begin{array}{c}5.63 \\
9\end{array}$ & $\begin{array}{c}4.0 \\
13\end{array}$ & $\begin{array}{c}0.091 \\
48\end{array}$ \\
\hline Model & $\begin{array}{c}41.6 \\
67\end{array}$ & 1 & $\begin{array}{c}41.6 \\
67\end{array}$ & $\begin{array}{c}5.84 \\
9\end{array}$ & $\begin{array}{c}4.0 \\
13\end{array}$ & $\begin{array}{c}0.094 \\
565\end{array}$ \\
\hline $\begin{array}{c}\text { Interaksi } \\
\text { Gender* } \\
\text { Model }\end{array}$ & $\begin{array}{c}78.1 \\
51\end{array}$ & 1 & $\begin{array}{c}78.1 \\
51\end{array}$ & $\begin{array}{c}10.9 \\
70\end{array}$ & 4.0 & 0.13 \\
\hline Dalam & 398. & 5 & 7.12 & & & 806 \\
\hline Total & 945 & 6 & 4 & & & \\
\hline
\end{tabular}

Berdasarkan tabel di atas, terlihat bahwa pada baris model nilai $\mathrm{F}_{0}$ sebesar 5,849 dan nilai $\mathrm{F}_{\text {tab }}$ sebesar $4,013\left(\mathrm{~F}_{0}>\mathrm{F}_{\mathrm{tab}}\right)$ dan dengan pengaruh sebesar $9,45 \%$. Hal ini menunjukkan bahwa terdapat perbedaan motivasi belajar siswa yang belajar melalui model pembelajaran kooperatif dengan model pembelajaran kontekstual berbantuan software geogebra.

Pada baris gender*model, nilai $\mathrm{F}_{0}$ sebesar 10,970 dan $\mathrm{F}_{\text {tab }}$ sebesar 4,013 $\left(\mathrm{F}_{0}>\mathrm{F}_{\text {tab }}\right)$. Hal ini menunjukkan bahwa terdapat interaksi antara model pembelajaran (kooperatif dan kontekstual) berbantuan software geogebra dengan gender siswa terhadap motivasi belajar siswa. Hal ini juga dapat dideskripsikan pada gambar berikut:

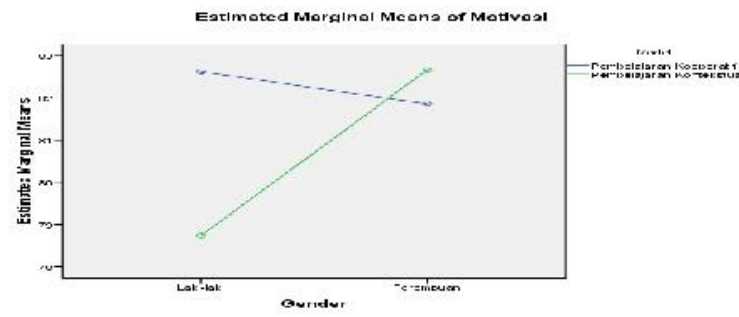

Gambar 2. Interaksi Antara Model Pembelajaran dan Gender Terhadap Motivasi Belajar Siswa Proses Jawaban Siswa

Secara keseluruhan jumlah siswa yang memperoleh kategori "baik" dari kedua kelas eksperimen dideskripsikan pada Tabel 9 berikut:

Tabel 9. Jumlah Siswa dengan Proses Jawaban dalam K ategori "Baik"

\section{No Eksperimen I $\quad$ Eksperimen II}

r yang Diajar Melalui Model Pembelajaran Kooperatif dengan Kontekstua 


\begin{tabular}{|c|c|c|c|c|c|c|c|c|}
\hline $\begin{array}{l}\text { So } \\
\text { al }\end{array}$ & $\begin{array}{c}\text { T. } \\
\text { I }\end{array}$ & $\begin{array}{l}\text { T. } \\
\text { II }\end{array}$ & $\begin{array}{c}\text { T.I } \\
\text { II }\end{array}$ & $\begin{array}{l}\text { T.I } \\
\text { V }\end{array}$ & $\begin{array}{c}\text { T. } \\
\text { I }\end{array}$ & $\begin{array}{l}\text { T. } \\
\text { II }\end{array}$ & $\begin{array}{l}\text { T.I } \\
\text { II }\end{array}$ & $\begin{array}{l}\text { T.I } \\
\text { V }\end{array}$ \\
\hline \multirow{3}{*}{1} & 1 & & & & 1 & & & \\
\hline & 6 & 5 & 2 & 5 & 8 & 9 & 1 & 6 \\
\hline & 1 & & & & 2 & & & \\
\hline \multirow[t]{2}{*}{2} & 9 & 20 & 11 & 5 & 2 & 21 & 16 & 15 \\
\hline & 2 & & & & 2 & & & \\
\hline \multirow[t]{2}{*}{3} & 0 & 16 & 5 & 8 & 2 & 21 & 13 & 10 \\
\hline & 1 & & & & 2 & & & \\
\hline 4 & 5 & 4 & 2 & 4 & 3 & 4 & 4 & 5 \\
\hline
\end{tabular}

Berdasarkan tabel di atas, secara keseluruhan jumlah siswa yang berada pada kategori baik pada kelas eksperimen II lebih banyak dibandingkan pada kelas eksperimen I (N Eksp. I < N Eksp. II), sehingga dapat dinyatakan bahwa proses penyelesaian jawaban siswa pada kelas eksperimen II (model pembelajaran kontekstual) lebih baik daripada kelas eksperimen I (model pembelajaran kooperatif).

\section{PEMBAHASAN \\ Faktor Model Pembelajaran}

Model pembelajaran kooperatif yang merupakan suatu strategi belajar mengajar yang menekankan pada sikap/perilaku bersama dalam bekerja atau membantu di antara sesama dalam struktur kerjasama yang teratur dalam kelompok, yang terdiri atas 2 orang atau lebih untuk memecahkan masalah (Karli dan Yuliariatiningsih, 2002), lebih mengutamakan kerjasama dalam menyelesaikan permasalahan untuk menerapkan pengetahuan dan keterampilan dalam rangka mencapai tujuan pembelajaran sehingga hasil belajar akademik siswa semakin meningkat dan siswa dapat menerima berbagai keragaman dari temannya, serta memperoleh pengembangan keterampilan sosial.

Hal tersebut didukung oleh teori belajar Vygotsky yang lebih memfokuskan perhatian kepada hubungan dialektika antarindividu dan masyarakat dalam pembentukan pengetahuan tersebut. Menitikberatkan pada aspek sosiokultural dalam pembelajaran, yaitu interaksi sosial melalui dialog dan komunikasi verbal dengan orang dewasa. Karena terdapat saling pengaruh antara bahasa dan tindakan dalam kondisi sosial (Dahar, 2006). Vygotsky memandang bahwa bahasa adalah pusat dalam proses belajar (Oakley, 2004). Adanya interaksi sosial dengan teman sebaya (tutor sebaya) atau bahkan dengan gurunya, akan mempengaruhi keterampilan komunikasi siswa dalam pembelajaran. Dengan demikian, adanya interaksi sosial antar siswa dalam suatu kelompok maupun dengan kelompok lain serta tanggungjawab bersama dalam kelompok dan dilengkapi dengan guru yang berperan sebagai motivator, fasilitator dan moderator akan memungkinkan diskusi yang lebih berkualitas dan pembelajaran yang lebih efektif.

Disamping itu, teori belajar bermakna dari Ausubel dan teori belajar konstruktivisme juga merupakan teori yang menguatkan model pembelajaran kooperatif. Teori belajar konstruktivisme memandang bahwa

Perbedaan Kemampuan Pemecahan Masalah dan Motivasi Belajar yang Diajar Melalui Model Pembelajaran Kooperatif dengan Kontekstual Berbantuan Geogebra

dalam proses belajar mengajar, perolehan pengetahuan diawali dengan terjadinya konflik kognitif (Karli dan Yuliariatiningsih, 2002a). Bell, dkk. (dalam Karli dan Yuliariatiningsih, 2002a) menyatakan bahwa konflik kognitif ini hanya bisa diatasi melalui pengetahuan diri (self-regulation). Pada akhir proses belajar, pengetahuan akan dibangun sendiri oleh anak melalui pengalamannya dari hasil interaksi dengan lingkungannya. Teori belajar bermakna dari Ausubel menekankan pentingnya siswa mengasosiasikan pengalaman, fenomena, dan fakta-fakta baru ke dalam struktur kognitifnya. Keduanya menekankan pentingnya asimilasi pengalaman ke dalam struktur kognitif dan menekankan bahwa proses belajar adalah dengan cara siswa aktif.

Model pembelajaran kontekstual merupakan suatu pendekatan yang menekankan kepada proses keterlibatan siswa secara penuh untuk dapat menemukan materi yang dipelajari dan menghubungkannya dengan situasi kehidupan nyata, sehingga mendorong siswa untuk dapat menerapkannya dalam kehidupan mereka. Model pembelajaran kontekstual erat kaitannya dengan kehidupan sehari-hari (konteks pribadi, sosial, dan kultural) sehingga dengan demikian siswa memiliki pengetahuan/keterampilan yang secara fleksibel dapat diterapkan dari satu permasalahan ke permasalahan lainnya. Dengan demikian, hasil pembelajaran diharapkan lebih bermakna bagi siswa. Proses pembelajaran berlangsung lebih alamiah dalam bentuk kegiatan siswa bekerja dan mengalami, bukan transfer pengetahuan dari guru ke siswa semata. Oleh karena itu, peran guru bukan hanya sebagai penyampai informasi tetapi juga sebagai fasilitator, mediator, dan sebagai pendamping sekaligus rekan kerja siswa dalam menemukan pengetahuannya.

Model pembelajaran kontekstual dengan komponen-komponennya adalah model pembelajaran yang didukung oleh banyak teori belajar. Teori kontsruktivisme, yakni menekankan pentingnya siswa membangun atau mengkontsruk pengetahuannya sendiri, teori belajar Dewey tentang pentingnya bertanya dan refleksi dalam pembelajaran. Teori belajar Piaget tentang sangat penting adanya penilaian yang autentik dan belajar dengan menemukan sendiri pengetahuan siswa pada saat proses pembelajaran, teori belajar Ausubel yang menekankan betapa pentingnya belajar yang bermakna, teori belajar Bruner yang juga mengemukakan tentang pentingnya belajar penemuan, teori belajar Vygotsky, Piaget dan Bruner tentang pentingnya belajar secara berkelompok.

Sebelum model pembelajaran kooperatif dan model pembelajaran kontekstual diterapkan, terlebih dahulu guru memberikan tes diagnostik untuk melihat kemampuan awal matematis siswa. selain itu, diberikan juga angket motivasi belajar untuk melihat seberapa besar motivasi belajar siswa sebelum diterapkannya pembelajaran. Pada saat model pembelajaran diterapkan, siswa diberikan Lembar Aktivitas Siswa (LAS) untuk dibahas secara berkelompok sesuai dengan petunjuk guru. Adanya tanggungjawab bersama 
dan pengakuan penghargaan dalam model pembelajaran kooperatif membuat siswa lebih bersemangat dan termotivasi dalam menyelesaikan LAS dan dalam diskusi. hal tersebut sesuai dengan pernyataan dari Duff (2012) menyatakan bahwa secara umum pelajaran yang diajarkan dengan pembelajaran kooperatif lebih menyenangkan dan siswa dapat mengkoneksikan materi dengan hidup mereka sendiri. Kegiatan belajar mengajar pada masa pertengahan pembelajaran dan tes latihan juga mencerminkan lingkungan belajar siswa pada pembelajaran kooperatif lebih memungkinkan siswa untuk mendapat kesempatan memahami materi yang dipelajari.

Selain itu, Vijayakumari dan D'Souza (2013) menyimpulkan bahwa pembelajaran kooperatif memiliki pengaruh positif terhadap prestasi belajar matematika siswa sekolah menengah.

Dalam penelitian ini, kedua model pembelajaran di atas didukung lagi oleh pengintegrasian ICT dalam pembelajaran, yakni dengan software GeoGebra. Hal ini tentunya memiliki kontribusi dalam mendukung keefektifan pembelajaran. Hal ini sesuai dengan penelitian dari Arbain dan Shukor (2015) yang menunjukkan bahwa siswa memiliki persepsi positif terhadap pembelajaran dan memperoleh prestasi belajar yang lebih baik dengan menggunakan GeoGebra.

\section{Kemampuan Pemecahan Masalah Matematis Siswa}

Berdasarkan hasil analisis data secara deskriptif sebelum diberi perlakuan, siswa di kedua kelas memiliki kemampuan pemecahan masalah matematis yang tidak berbeda secara signifikan. Hal ini dapat dilihat dari rata-rata skor tes diagnostik kelas eksperimen I dan eksperimen II masing-masing adalah 52,71 dan 53,49. Setelah diberi perlakuan, kemampuan pemecahan masalah matematis siswa yang belajar dengan model pembelajaran kontekstual lebih tinggi dari siswa yang belajar dengan model pembelajaran kooperatif. Hal ini ditunjukkan oleh rata-rata skor post test kelas eksperimen I yaitu 70,47, sementara di kelas eksperimen II sebesar 74,70.

Pada kegiatan pembelajaran, siswa yang berkemampuan tinggi, sedang, dan rendah, dan dari jenis kelamin laki-laki maupun perempuan lebih aktif dalam melakukan diskusi pada kelas eksperimen I. Dengan adanya saling ketergantungan antar siswa dalam kelompok menjadikan adanya diskusi interaktif dan saling bertukar pikiran antar siswa dalam kelompok tersebut. Ditambah lagi adanya pengumunan pengakuan dan penghargaan di akhir pembelajaran kooperatif menjadikan siswa dalam kelompok semakin termotivasi dalam memecahkan masalah yang diberikan untuk bersaing dengan siswa dari kelompok lain. Akan tetapi, pada kelas eksperimen II, adanya kegiatan questioning dan modelling dalam model pembelajaran kontekstual mampu meningkatkan pemahaman siswa terhadap materi yang sedang dipelajari. Dalam hal ini, siswa tidak terlalu aktif bersaing dalam diskusi, mereka hanya terlibat dalam tanya jawab pada hal yang mereka kurang pahami saja. Pemahaman siswa lebih baik lagi dengan adanya kegiatan modelling yang menyajikan model sebagai contoh yang sebenarnya. Sehingga siswa benar paham dengan yang dipelajari dan menjadikan kegiatan pembelajaran yang bermakna.

\section{Interaksi Antara Model Pembelajaran dan Gender terhadap Kemampuan Pemecahan Masalah Matematis Siswa}

Kerlinger (1986) menyatakan bahwa "interaksi terjadi manakala suatu variabel bebas memiliki efekefek yang berbeda terhadap suatu variabel terikat pada berbagai-bagai tingkat dari suatu variabel bebas lain". Dalam hal ini yang diteliti adalah kerjasama antara model pembelajaran (kooperatif dan kontekstual) dengan gender terhadap kemampuan pemecahan masalah matematis siswa.

Hasil analisis deskriptif kemampuan pemecahan masalah matematis siswa, diperoleh bahwa siswa lakilaki di kelas eksperimen I dengan nilai rata-rata 66,31 dan siswa perempuan dengan nilai rata-rata 75,00. Hal ini menunjukkan bahwa kemampuan pemecahan masalah matematis siswa laki-laki lebih rendah dibandingkan dengan siswa perempuan untuk kelas ekperimen I. Sedangkan siswa laki-laki pada kelas eksperimen II dengan nilai rata-rata 77,79 dan siswa perempuan dengan nilai rata-rata 76,02. Dengan demikian dapat dinyatakan bahwa kemampuan pemecahan masalah matematis siswa laki-laki lebih tinggi dibandingkan dengan siswa perempuan untuk kelas ekperimen II.

Berdasarkan hasil analisis statistik inferensial dengan uji ANAVA dua jalur pada baris gender*model diperoleh nilai sig.0,042 (sig. $<0,05$ ), maka dapat disimpulkan bahwa terdapat interaksi antara model pembelajaran (kooperatif dan kontekstual) dengan gender terhadap kemampuan pemecahan masalah matematis siswa dengan pengaruh sebesar $6,82 \%$. Hal ini sesuai dengan yang dikemukakan Murtafiah dan Amin (2018) bahwa gaya kognitif dan gender secara bersama-sama berpengaruh secara signifikan terhadap kemampuan pemecahan masalah matematika siswa. Disamping itu, Pramawati, Dantes, dan Parmiti (2016) menyimpulkan bahwa terdapat interaksi yang signifikan antara model pembelajaran dan jenis kelamin terhadap keterampilan berpikir kreatif siswa. Seiring demikian, Katminingsih dan Widodo (2015) menyatakan bahwa kemampuan berpikir kreatif matematis siswa laki-laki lebih baik daripada kemampuan berpikir kreatif matematis siswa perempuan dan terdapat interaksi antara model (PBM dan konvensional) dengan gender terhadap kemampuan berpikir kreatif matematis siswa.

\section{Interaksi Antara Model Pembelajaran dan Gender Terhadap Motivasi Belajar Siswa}

Berdasarkan hasil analisis deskriptif, diperoleh bahwa motivasi belajar siswa laki-laki di kelas eksperimen I dengan skor rata-rata 82,54 dalam kriteria "baik" dan siswa perempuan dengan skor rata-rata 81,6 juga dalam kriteria "baik". Hal ini menunjukkan bahwa motivasi belajar siswa laki-laki setelah diberi perlakuan 
lebih tinggi dibandingkan dengan siswa perempuan untuk kelas ekperimen I. Sedangkan motivasi belajar siswa laki-laki pada kelas eksperimen II dengan skor rata-rata 78,57 dalam kriteria "baik" dan siswa perempuan dengan nilai rata-rata 82,6 juga dalam kriteria "baik". Dengan demikian dapat dinyatakan bahwa kemampuan motivasi belajar siswa laki-laki setelah diberi perlakuan lebih rendah dibandingkan dengan siswa perempuan untuk kelas eksperimen II.

Berdasarkan hasil analisis statistik inferensial dengan Uji ANAVA dua jalur pada baris gender*model diperoleh nilai sig.0,001 (sig.< 0,05), maka dapat disimpulkan bahwa terdapat interaksi antara model pembelajaran (kooperatif dan kontekstual) dengan gender terhadap motivasi belajar siswa dengan pengaruh sebesar $16,38 \%$. Hal ini sesuai dengan hasil penelitian yang dilakukan Chua dan Karpudewan (2015) yang berjudul "The Interaction Effect of Gender and Grade Level on Secondary School Students Attitude toward Learning Chemistry" menyatakan bahwa terdapat interaksi antara gender dan tingkat kelas terhadap sikap belajar siswa terhadap pelajaran kimia.

\section{KESIMPULAN}

Berdasarkan hasil analisis data penelitian tentang kemampuan pemecahan masalah matematis dan motivasi belajar siswa yang belajar melalui model pembelajaran kooperatif dan model pembelajaran kontekstual berbantuan software GeoGebra, maka diperoleh beberapa kesimpulan sebagai berikut:

1. Terdapat perbedaan kemampuan pemecahan masalah matematis siswa yang belajar melalui model pembelajaran kooperatif dengan model pembelajaran kontekstual berbantuan software GeoGebra.

2. Terdapat perbedaan motivasi belajar siswa yang belajar melalui model pembelajaran kooperatif dengan model pembelajaran kontekstual berbantuan software GeoGebra.

3. Terdapat interaksi antara model pembelajaran dan gender terhadap kemampuan pemecahan masalah matematis siswa

4. Terdapat interaksi antara model pembelajaran dan gender terhadap motivasi belajar siswa

5. Proses penyelesaian jawaban siswa kelas model pembelajaran kontekstual lebih baik dibandingkan kelas model pembelajaran kooperatif.

\section{UCAPAN TERIMA KASIH}

Pada kesempatan ini, penulis mengucapkan terimakasih kepada:

1. Bapak Prof. Dr. Bornok Sinaga, M.Pd selaku Direktur Program Pascasarjana UNIMED yang telah memberikan kesempatan serta bantuan administrasi selama pendidikan di Universitas Negeri Medan, sekaligus sebagai dosen penguji yang telah memberikan sumbangsih pemikiran konstruktif untuk tesis ini.

2. Bapak Prof. Dr. Edi Syahputra, M.Pd selaku Ketua Prodi Pendidikan Matematika Pascasarjana
UNIMED sekaligus sebagai penguji yang telah memberikan masukan kepada penulis dalam penulisan tesis ini.

3. Bapak Dr. Mulyono, M.Si selaku sekretaris Prodi Pendidikan Matematika Pascasarjana UNIMED dan juga sebagai penguji yang telah memberikan banyak kritik, masukan, dan saran perbaikan yang bersifat membangun dalam tesis ini.

4. Ibu Dr. Ani Minarni, M.Si, selaku Pembimbing I dan Bapak Prof. Dr. Mukhtar, M. Pd yang telah memberikan arahan dan bimbingan serta motivasi yang sangat bermanfaat dan berharga bagi penulis dalam penyusunan tesis ini sampai dengan selesai.

5. Bapak Dr. W. Rajagukguk, M. Pd selaku penguji yang telah memberikan masukan dan sumbangan pemikiran sehingga menambah wawasan pengetahuan penulis dalam penyempurnaan penulisan tesis ini.

6. Kepada keluarga tercinta Ayahanda Salmer Saragih, Ibunda Rapinna Sitopu, Kakanda Rohmaita Fitriani Saragih, Ananda Erik Pranata Saragih, serta Adinda Ike Novella Saragih yang selalu mendo'akan, memberikan motivasi, dukungan moril maupun materil kepada penulis sehingga tesis ini terselesaikan dengan baik.

7. Teman-teman seperjuangan kelas A-2 Pendidikan Matematika PPs UNIMED 2016 serta segenap pihak yang berpartisipasi membantu penulis dalam menyelesaikan tesis ini yang tidak dapat penulis sebutkan satu persatu

\section{REFERENSI}

Arbain, N. \& Shukor, N. A. 2015. The effects of GeoGebra on Students Achievement. ProcediaSocial and Behavioral Science. No. 172 Pp: 208214

Dahar, R. W. 2006. Teori-Teori Belajar dan Pembelajaran. Jakarta: Erlangga.

Darmawijoyo. 2011. Pembelajaran Matematika Berbasis Web. Jurnal Sistem Informasi (JSI), Vol. 3 No. 1 Hal. 294-303

Dimyati dan Mudjiono. 2013. Belajar dan Pembelajaran. Jakarta: Rineka Cipta

Dornyei, Z. 2001. Teaching and Researching Motivation. Pearson Education Limited: Edinburgh Gate.

Duff, J. 2012. Cooperative Learning vs. Direct Instruction: Using two Instructional Models to Determine their Impact on Student Learning in a Middle School Math Classroom. Education Senior Action Research Projects. Valparaiso University. Pp. 1-4

Escuder, A. \& Furner, J. M. 2012. The Impact of GeoGebra in Math Teachers' Professional Development. Florida Atlantic University. Pp: 76-84

Guvendir, M. A. 2016. Students' Extrinsic and Intrinsic Motivation Level and Its Relationship with Their Mathematics Achievement. International Journal for Mathematics Teaching and Learning. Pp. 121.

Perbedaan Kemampuan Pemecahan Masalah dan Motivasi Belajar yang Diajar Melalui Model Pembelajaran Kooperatif dengan Kontekstual Berbantuan Geogebra 
Husna, Ikhsan, M., \& Fatimah, S. 2013. Peningkatan Kemampuan Pemecahan Masalah dan Komunikasi Matematis Siswa Sekolah Menengah Pertama Melalui Model Pembelajaran Kooperatif Tipe Think-Pair-Share (TPS). Jurnal Peluang, Vol. 1. No. 2. Hal: 81-92.

Jariswandana, L., Yerizon, \& Nilawasti, Z. A. 2012. Meningkatkan Motivasi Belajar Matematika Siswa dengan Penerapan Model Pembelajaran Kooperatif Tipe Think Talk Write. Jurnal Pendidikan Matematika. Vol. 1 No. 1. Hal. 81-86

Karli, H \& Yuliariatiningsih, M.S. 2002a. Implementasi KBK 1. Jakarta: Bina Media Informasi.

Kerlinger, F. N. 1986. Azas-azas Penelitian Behavioral Edisi Ketiga (terjemahan L. R. Simatupang). Yogyakarta: Gadjah Mada University Press.

Laili, H. 2016. Pengaruh Model Pembelajaran Contextual Teaching and Learning (CTL) Dalam Meningkatkan Kemampuan Pemecahan Masalah Matematika Siswa MTs Nurul Hakim Kediri Ditinjau dari Segi Gender. Jurnal Studi Keislaman dan Ilmu Pendidikan. Vol. 5 No. 2 Hal: 34-52

Minarni, A. 2017. On Eight Grade Students Understanding in Solving Mathematical Problems. Asian Social Science. Vol. 13 No. 12 Pp: 86-96

Meece, J. L.,Glienke, B. B., \& Burg, S. 2006. Gender And Motivation. Journal of School Psychology. Vol. 44. No. 5 Pp: 351-373

Nayazik, A. 2012. Pembelajaran Matematika dengan Mengintegrasikan HOM (History Of Mathematics) Untuk Meningkatkan Motivasi Belajar. Prosiding Pendidikan Matematika UNY. Hal: $1-8$

Oakley, L. 2004. Cognitive Development. London: Routledge.

Ritonga, I. D., Surya, E. \& Syahputra, E. 2017. Analysis Problem Solving Ability on Flat Quadrilateral Material Of Students at Junior High School. IJARIIE. Vol. 3 Issue 2. Pp:3788-3792

Polya. 1973. How to Solve It A New Aspect of Mathematical Method. Princeton University Press.

Saha, R. A. Ayub, A. F. M., \& Tarmizi, R. A. 2010. The Effects of GeoGebra on Mathematics Achievement: Enlightening Coordinate Geometry Learning. Procedia Social and Behavioral Science. Vol. 8 Pp: 686-693

Saragih, D. I. 2017. Analysis the Effectiveness of Mathematics Learning Using Contextual Learning Model. International Journal of Sciences: Basic and Applied Research (IJSBAR).Vol. 34. No 1. Pp 135-143

Setiawati, D., Syahputra, E., \& Rajagukguk, W.R. 2017. Kemampuan Pemecahan Masalah Siswa melalui Pendekatan Contextual Teaching and Learning di Kelas X SMK Negeri 1 Bireuen. Jurnal Pendidikan Matematika PARADIKMA. Vol. 6 No. 1 Hal: 1-13
Tomljenovic, K dan Zovco,V. 2016. The Use of ICT in Teaching Mathematics - A Comparative Analysis of the Success of $7^{\text {th }}$ Grade Primary School Students. Croatian Journal of Education. Vol. 18 No. 2 Pp: $215-221$

Uno, H. B. 2014. Teori Motivasi dan Pengukurannya. Jakarta: Bumi Aksara

Vijayakumari, S. N. \& D'Souza, M. J. S. 2013. Metacognitive - Cooperative Learning Approach to Enhance Mathematics Achievement. International Journal of Education and Psychological Research (IJEPR). Vol. 2 Issue 2 Pp: 111-119

Wardhani, S., Wiworo, Guntoro, S. T., \& Sasongko, H. W. 2010. Pembelajaran Kemampuan Masalah Matematika di SMP. Yogyakarta: PPPPTK Matematika.

Wena, M. 2011. Strategi Pembelajaran Inovatif Kontempores. Jakarta: Bumi Aksara 